\title{
Challenges for the Distributed Leadership Development of Education Institutions in a Hierarchical National Culture
}

\begin{abstract}
The article analyses challenges for the distributed leadership development of education institutions in the context of hierarchical culture. According to theoretical research, it is possible to state that institutional environment in Lithuania provides possibilities for developing distributed leadership. Meanwhile, cultural environment is characterized by a high degree of hierarchy.
\end{abstract}

Keywords: distributed leadership, education institution, national culture, hierarchy.

Straipsnyje nagrinejjami Lietuvos švietimo ịstaigų pasidalytosios lyderystès principų plètros iššūkiai hierarchiškos kultūros kontekste. Remiantis teoriniu tyrimu, galima teigti, kad Lietuvos institucinio lygio aplinka sudaro galimybes šios lyderystès pletojimui. Tuo tarpu kultūrinè aplinka pasižymi dideliu hierarchiškumu.

Raktiniai žodžiai: pasidalytoji lyderysté, švietimo ịstaiga, nacionalinè kultūra, hierarchiškumas.

\section{Introduction}

In recent years, changes in the education sector have been determined by new documents regulating educational activities, such as "National Education Strategy 2013-2022" (2013) and "Good School Concept” (2015). A number of amendments have been made in "The Law on Education of the Republic of Lithuania" (1991), which have established new regulations on the assessment of the heads of state and municipal school (except higher education institutions), their deputies for education, the heads of education departments, moreover, the terms of office for heads have been introduced, etc. A lot of changes have been foreseen: in September
2018, the system of full-time payment for teachers will be introduced, and preprimary and primary education school age will be younger, what inevitably will determine changes in curricula. Recently, in Lithuania, there have been changed not only legal acts regulating educational activities, but also considerable attention has been paid to the dissemination of leadership ideas in education. Thus, it may be stated that the strategists of the Lithuanian education system hope to implement leadership as cultural change in educational organizations. The project "Time for Leaders" initiated by the Ministry of Education and Science significantly contributes to the dissemination of leadership ideas in Lithuania: the first stage was 
implemented in 2009-2011, the second stage in 2011-2015, and the third stage in 2017-2020. This project creates wider possibilities for promoting the autonomy of educational communities and improving the quality of education (Valuckiene et al., 2015). "Good School Concept" (Lietuvos Respublikos švietimo ir mokslo ministerija, 2015) also states that leadership and management are the factors that determine the school's mission. Alongside with the changes of state legal acts, society and individual organizations have to change as well, the need for different management structure and culture in organizations becomes relevant. Not only the rules of work and conduct, the structure of organizations have to change, but also the culture of organizations. Analysing these changes at the institutional level, it is possible to state that the institutes are changing in Lithuanian society. Firstly, formal institutes - formal restrictions - are changing, i.e. the rules purposefully set by people. Under the change of formal institutes, people's habits, rules of conduct have to change as well, though not so rapidly (North, 2010). According to D. North (2010), no matter how rapidly and radically formal institutes would change, non-formal rules of restrictions that exist in society and which lie in customs, traditions, and established rules of conduct, cannot change quickly and radically. According to the author, non-formal restrictions have special sustainability, as they are part of the habitual human behaviour and are changing much more slowly than formal restrictions. Even the ways by which formal and non-formal institutes are consolidated or changed, shape our daily lives, provide people with guidelines for their daily routines. According to D. North (2010), with the replacement of formal institutes, non-formal institutes (non-formal restrictions) usually remain unchanged for some time, and this leads to a constant tension between non-formal restrictions and formal rules that are incompatible with them. As noted by G. Jucevičius (2014), a sharp division between the emerging institutional framework and cultural environment supporting it can lead to undesirable side-effects and reduce the effectiveness of work of a country and its organizations (as social systems). However, according to G. Hofstede et al. (2010), not necessarily a successfully implemented idea in one country will also be successfully implemented in another country, because it is very important to take into account the national cultures of countries. As noted by I. Minelgaitè-Snaebjornsson, I. R. Edvardsson, and R. F. Littrell (2017), the influence of the socio-cultural environment on practice and processes of organizations has long been a significant topic for research in management science. The authors state that national culture is one of the most influential (situational) factors that determines organizational phenomena. However, as noted by I. MinelgaitéSnaebjornsson et al. (2017), the two largest original cross-cultural studies of G. Hofstede (1984) and GLOBE "Culture, Leadership, and Organizations: The GLOBE Study of 62 Societies" (House et al., 2004) did not include Lithuania. In terms of leadership and, in particular distributed leadership, researchers recognize that the context is important for the development of leadership as well. Different contexts of educational institutions also determine 
the need for different leadership and development in organizations (Kivunja, 2015; Heikka et al., 2012; Cibulskas et al., 2011). The contextuality of distributed leadership, dependence on people and situation are also emphasized by J. P. Sillane (2005). However, there is lack of evidence to situate distributed leadership in contextual and compositional situations at school. In addition, empirical research has shown that contexts of school and characteristics of principal are important indicators for school leadership (Liu et al., 2018). The literature review conducted by I. Minelgaite-Snaebjornsson et al. (2017) indicated the lack of comparative research on Lithuanian cultural and management implications.

According to G. Jucevičius (2014), the leading researchers of national culture (Hofstede, 1980; Laurent, 1983) state that cultural characteristics of a country are changing very slowly. Therefore, the following questions have been raised: Are all recent institutional and cultural changes in Lithuania culturally "matured", or is it just an attempt to adapt to international processes without regard to the cultural context of Lithuania and education organizations? Are there possible rapid cultural changes, the dissemination of leadership ideas in education institutions, which Lithuanian education strategists expect? What is the coherence between the institutional and cultural environment of Lithuania, i.e., are the laws regulating the Lithuanian education system timely and consistent with the cultural maturity of organizations?

The object of research: distributed leadership of education institutions.

The aim of research is to analyse the challenges for the development of distributed leadership in a hierarchical national culture.

\section{Objectives:}

1. To present a theoretical overview of distributed leadership.

2. To analyse the context of the institutional level of Lithuanian education institutions for the development of distributed leadership.

3. To analyse the cultural researchers' attitude towards the hierarchy as a cultural dimension.

4.To analyse the conditions for the development of principles of distributed leadership of education institutions in the context of hierarchical culture.

The methods of research. The analytical content analysis of theoretical literature and other sources (strategic documents and legal acts) was chosen to implement the research objectives in order to focus and generalize theoretical insights, to reveal the context, regularities and challenges of the development of distributed leadership in education institutions at institutional and cultural level, and to find new aspects for the research of distributed leadership.

\section{Distributed leadership}

Presently, distributed leadership is the dominant idea of management (Harris, 2012). According to A. Harris (2010), this is a form of leadership when the influence is made on an organization, and decisions are taken by several persons, rather than managing by one person. Distributed leadership is one of the leadership ways in achieving organizational aims (Harris and Spillane, 2008). Also, it is one of the ways to change institutional management 
(Valuckienè et al., 2015). The importance of community involvement in the organization's activities, support for the initiative, involvement in decision making, and the distribution of power and activity among the organization's employees are highlighted by K. Leithwood et al. (2006), A. Harris (2010), T. Duif et al. (2013), R. Dukynaitè (2015), etc. R. F. Elmore (2000) claims that all individuals differ in their abilities, competences, the nature of the performed work, and these abilities might be shared with others inside an organization. According to the author, in distributed leadership the attention should be paid to communication and collaboration, learning from each other. It is also important for community members to participate in the organization's activities, the support for the initiative, involvement into decision making, the distribution of power and activity among different staff members, formal and non-formal leaders (Leithwood et al., 2006; Harris, 2010; Duif et al., 2013; Dukynaite, 2015, etc.). Scientific literature emphasizes the importance of community members' trust in each other, formal and non-formal leaders, taking responsibility for the overall performance (Day et al., 2009; Duif et al., 2013; Elmore, 2000). According to K. Leithwood et al. (2006), in the process of implementing the ideas of distributed leadership, horizontal relations, management as interaction, and the creation of space for other's leadership become essential.

Distributed leadership can be seen as a change in organizations. While developing distributed leadership as a change in education institutions, the head's role is especially important, as different changes start namely in the head's office (A. Harris, 2012). According to J. Murphy et al. (2009), it usually depends on formal leaders whether other persons' initiative will self-develop, or the initiative will be suppressed. Firstly, a head has to re-orientate himself/herself and be able to refuse power and authority, to shift away from leadership as position to leadership as interaction with other members of an organization, and to build a high degree of reciprocal trust in formal and non-formal leadership (Harris, 2012). Formal heads, as stated by A. Harris (2010), have to be proactive and benevolent, and not assess other persons' leadership as the loss of their own power. Moreover, they have to avoid over-controlling others, they have to promote and assess innovative ideas coming from all members of the organization. Heads also have to feel time and space, to perceive the possibilities of others and to know when to withdraw, allowing other staff members to participate in decision making, to coordinate the overall activities (Leidhwood et al., 2006; Obadara, 2013). Heads have to focus not only on developing their leadership competences, but also on developing of the organization's infrastructure for successful leadership. J. Murphy et al. (2009) emphasize the importance of formal heads in changing an organization's structure and creating conditions for employees to meaningfully work together. Creating conditions for the development of other persons' initiative changes both the culture of an organization and the formal leader's role in an organization. The formation of a new culture in an organization, as noted by J. Murphy et al. (2009), starts when a head evaluates available culture, collating 
it with desired organizational culture, and later reforming the culture: by developing and supporting employees' leadership and further managing for distributed leadership.

R. Gill (2003) and J. Hayes (2010) observe that effective leadership is necessary for changes. As it is claimed by A. Harris (2008), there would seem to be evidence from the literature that distributing leadership also can have a positive impact on organisational development and change. Therefore, distributed leadership is often assessed by researchers as the basis for successful implementation of changes in an organization. As noted by A. Harris $(2008 ; 2010)$, there are a lot of studies that analyse the impact of distributed leadership on organizational performance and change. According to D. North (2003), the way knowledge is developed in an institution shapes people's worldview. People's belief that the structure of rules within an organization is fair and honest facilitates the implementation of changes, and vice versa - the belief that it is not fair and honest destroys it. Therefore, it can be argued that if there is distributed leadership in an organization (the community is actively involved in an organization's activities, their initiative is supported, members of the community are involved in the organization's decision making), it increases the people's belief that the structure of the rules within an organization is correct.

A. Harris (2008) emphasizes different strategies for developing distributed leadership: superficial level of distributed leadership, when in the development of leadership new teams are created, new roles and responsibilities are taken and shared; subterranean level of distributed leadership, when sharing the leadership becomes the norm of work; deep level of distributed leadership, which is seen in the culture of an organization. Consequently, sustainable and planned distributed leadership can also contribute to successful implementation of other changes in an organization and to be a solid ground for formal leaders to manage effectively in the future. A. Harris (2008) states that there are three main barriers that make distributed leadership difficult to achieve: distance (the physical space can be a barrier to distributed leadership as the geographic separation makes it more difficult for teachers to connect with each other); culture (shift in culture away from the "top down" model of leadership to a form of leadership that is more organic, spontaneous and more difficult to control); structure (the structure of schooling is still dominated by compartmentalising subjects, pupils and learning into discrete but manageable boxes).

In summing up, it is possible to state, that researchers distinguish the following features of distributed leadership: the community members' participation in the organization's performance, communication and collaboration, tea ching/learning from each other, support for the initiative, involvement in decision making, and the distribution of power and activity among other employees of the organization. Distributed leadership in an organization is important in several aspects. First of all, distributed leadership helps to better achieve organizational goals. Already implemented distributed leadership is useful for the successful implementation of other changes. The formal heads of education institutions play an important role in 
developing distributed leadership. It often depends on them what conditions will be created for the development of leadership in an organization, whether the structure and culture of an organization will be changed.

\section{The context of Lithuanian institutional level in the development of distributed leadership}

According to D. Dambrauskiene and L. Liukinevičiene (2017), recently, the necessity for changes in society and leadership, the importance of management competences in communities and institutions have been emphasized. Moreover, the changes in the Lithuanian education sector have been determined by the education reform. As noted by the authors, the documents formalizing changes in the state's educational policy seek to improve organizational management, interaction with local communities, social partners, other education institutions, etc. The obvious shift of educational policy in Lithuania to the development of leadership as well as distributed leadership in education institutions is discussed in the following documents:

Lithuanian Progress Strategy "Lithuania 2030" (Lietuvos Respublikos Seimas. Lietuvos pažangos strategija „Lietuva 2030", 2013) focuses on smart governance, i.e., the development of leadership and governance competences not only in institutions of central and local authorities but also in communities.

Lithuanian Progress Strategy 20132022 (Lietuvos Respublikos švietimo ir mokslo ministerija, 2013) indicates that the dynamic interaction between education institutions and the members of society in creating smart society is an essential factor for success. It is emphasized that leadership should involve the abilities of members of education sector and social partners to reach the aim of education, whilst management has to become more expedient and communal.

The Law on Education of the Republic of Lithuania (Lietuvos Respublikos Seimas. Lietuvos Respublikos švietimo istatymas, 1991) emphasizes the importance of interaction with the community of an education institution, governance of a democratic institution, cooperationbased relationships, taken transparent decisions, and informing members of the community. Since 2017, the amendments to the Law on Education have introduced the new requirements for heads of education institutions: the impeccable reputation of the head of an education institution has been emphasized, the fiveyear term of office has been introduced, and the certification of heads has been refused. The new substatutory legal acts implementing the law on education also foresee new procedures for the evaluation of heads of education institutions. In 2018, the regulations for the performance evaluation of heads of state and municipal education establishments (except higher education institutions), their deputies for education, heads of education departments have been approved. These new regulations are of great significance to the institution's community when assessing the activities of the head of education institution. The school head presents an annual activity report to the community of 
the education institution and the council of the institution, which not only evaluates the head's performance report, but also makes a decision on the assessment of the school head's annual performance.

The Concept of a Good School (Lietuvos Respublikos švietimo ir mokslo ministerija, 2015) emphasizes that management and leadership have to be shared. It is emphasized that the major part of decisions is made by the school's community, its different members manage activities, their personal initiative is promoted.

In the future, the Lithuanian education community will witness a lot of changes as well. Since September 2018, education institutions in Lithuania will transfer to full-time salary payment for teachers. It is expected that this will attract more young teachers to education institutions, provide teachers with more stability and security. This will lead to the successful implementation of distributed leadership and other changes in Lithuanian education institutions.

Recently, a lot of attention has been paid not only to the change of normative legislation, but also to the restructuring of organizational structure of Lithuanian education institutions (general education schools), as well as to the cultural changes of communities of education institutions, i.e. the dissemination of leadership ideas. An example of this is the project "Time for Leaders" initiated by the Ministry of Education and Science. The first stage of this project took place in 2009-2011, the second - in 2011-2015, the third is foreseen in 2017-2020. The communities of education of the remaining 45 municipalities of Lithuania have been included to participate in the third stage of the project. The project "Time for Leaders" creates wider possibilities in developing leadership competences of education communities and strengthening the decentralization of education governance, promoting self-dependence of education communities and improving education quality (Valuckiene et al., 2015). Fifteen municipalities participating in the project have created unique models for development of leadership (see: http://www.lyderiulaikas.smm.lt/). Longitudinal studies were conducted (Beresnevičiūtè et al., 2011; Katiliūtè et al., 2013). The monograph "Leadership for Learning: Theory and Practice for School Change" was published on the basis of the third longitudinal study (Valuckienè et al., 2015).

Since 2017, implementing the external assessment of the activities of general education schools, the attention has been paid to the four areas of the school's activities, one of which is Leadership and Management (Order No. V-322 of the Minister of Education and Science of the Republic of Lithuania of 2 May 2017). The distributed leadership is emphasised, i.e., the development of leadership skills is promoted, giving all members of the community the freedom to show initiative, take responsibility for initiatives, decisions, and their implementation. Leaders involve and promote community to debate, think and act creatively.

In conclusion, it is possible to state that the new normative documents underlying Lithuanian strategic direction and providing the guidelines for the state education system, as well as leadership promoting project "Time for Leaders", which has been funded for almost ten years by the state, clearly shows the state's desire to 
change the Lithuanian education system. In other words, to change moral values in education institutions, to strengthen the role of communities in management of organizations, and to change the culture of management of educational organizations. According to D. North (2003), the rules of society's game are changing, and a new interaction among people in the organizations and in society itself is developing. According to E. Brousseau et al. (2011), the institutes do not change in their own right, and people themselves create formal institutes, i.e. they create new rules, the new culture of communication and decision making. This externally driven change forces the leaders of organizations not only to change the management and structure of organizations (which is easier achieved by adopting certain managerial decisions), but also the culture of organizations (community values, customs, the usual way of working and communicating, established relations and traditions of activities). According to G. Roland (2004), it is possible to categorize the changes that take place in the organizations: the transformation of an organization's culture to "slowly changing" organizations and the structural transformation of organizations, the transformation of the internal document system to "rapidly changing" institutes.

\section{The attitude of cultural researchers towards hierarchy as a cultural dimension}

The need to understand how culture affects management has grown along with increased globalization (North- ouse, 2013). Researchers pay significant attention to the studies of both culture in general and national cultural. Researching culture, different researchers define it differently. A. L. Kroeber and C. Kluckhohn (1952) distinguished over 160 different descriptions of culture. G. Jucevičius (2014) states that there are a lot of different methodologies which on the basis of values define the diversity of national cultures (Parsons and Shils, 1951; Kluckhohn and Strodtbeck, 1961; Hall, 1965; 1976; Rokeach, 1968; Adler, 1986; Laurent, 1986; Trompenaars, 1984; 1993 , etc.). As noted by G. Jucevičius (2014), the concept of cultural dimensions proposed by G. Hofstede (1980) is perhaps the most widespread and widely cited in intercultural studies. According to G. Hofstede (2007), culture is the collective programming of the mind which separates one group of people from another. In the author's opinion, symbols, heroes, rituals and values shape culture. G. Hofstede (2007) notes that culture is collective, not an individual attribute, not directly visible but manifested in behaviours, and common to some, but not all people. According to G. Hofstede et al. (2010), culture consists of the unwritten rules of the social game. The researcher has identified four cultural dimensions that make it possible to describe the important aspects of national culture and to compare individual cultures: individualism-collectivism, uncertainty avoidance, power distance, and masculinity-femininity. The model was based on survey conducted from 1968 to 1972 on IBM subsidiaries in 40 countries (Hofstede, 1984). The absolute meaning of the cultural dimension does not reveal anything, 
therefore, it is necessary to look at differences in the meanings of the dimensions within the same sample of respondents in different countries and then to make comparative conclusions. The scale of the dimensional values is usually given from 0 to 100 , the distinctive pole limit is approximately at 50 (Jucevičius, 2014). G. Hofstede et al. (2010) define one of the four dimensions, the power distance, as the strength of the social hierarchy. Evaluating this dimension, the problem is solved how to handle the fact that people are unequal. The distance of power reflects the hierarchy of society. According to G. Jucevičius (2014), high power distance organizations and countries have hierarchical structures, centralized decision making, often authoritarian leadership style. Meanwhile, low power distance organizations and countries have decentralized organizational structures, there are more democratic relationships among heads and subordinates in organizations. According to G. Hofstede, et al. (2010), in a society with different distance of power, the relations are different not only in the organization itself, but between parents and children, between pupils and teachers. In high power distance countries, teachers are treated with respect, sometimes even with fear. Qualitative education in such countries is highly dependent on teachers' competence. Meanwhile, in low power distance countries, teachers and pupils are treated as equal. The educational process is pupil-centered. Pupils have the right to interrupt teaching, ask questions, express controversy, criticize (at the same time respecting the teacher). Effective learning in such system greatly depends on the interaction between teacher and pupil. As noted by authors, in different power distance countries, education institutions of different level are differently state-funded. In low power distance countries, more funding is provided, education policy focuses on secondary education, and in high power distance countries, education policy focuses on universities. It is clear that the relationship between low and high power distance in education institutions also affects the head-subordinate relationship. According to G. Hofstede, et al. (2010), in high power distance, heads and subordinates evaluate each other as not equal, and a hierarchical system is based on this inequality in an organization. Subordinates expect heads to point out what to do, there is a lot of controlling, supervising staff. Relationships between heads and subordinates are emotional. Meanwhile, in low power distance countries, heads and subordinates are equal to each other in terms of existential approach. According to the authors, a hierarchical system manifests itself only in the inequality of performed functions, which is devoted for more convenient management and can be easily changed. Organizations are rather decentralized, and there is a relatively limited number of supervisory staff. Subordinates expect from the head a democratic management, and also expect that the head will consult with them before making decisions that might affect their work. Also, they agree with the opinion that the head is the one who makes the final decisions. Relations between subordinates and heads are pragmatic. As noted by G. Hofstede et al. (2010), in high power distance countries subordinates may be disturbed if the head asks for their opinions before 
making a decision or even stop to respect their head.

As noted by I. Minelgaitè-Snaebjornsson et al. (2017), studies by G. Hofstede have provided evidence that national culture has an infl uence on governance and leadership in an organization.

\section{The conditions for the development of distributed leadership of education institutions in the context of hierarchical culture}

In Lithuania, national culture in different aspects was researched by A. Mockaitis (2002; 2005), A. Mockaitis and L. Šalčiuvienè (2004), M. Huettinger (2008), A.Stelmokienè (2012), G. Jucevičius (2014), I. Minelgaitè-Snaebjornsson et al. (2017), etc. According to G. Hofstede et al. (2010), cultural differences are determined by the region, nationality, religion, gender, generation, and social class. Analysing Lithuanian society, M. Huettinger (2008) notes that there are three different generations in Lithuania: elderly people who were born before the World War II, the generation that grew up in the Soviet times, and younger people who were born and grew up in the independent Lithuania. It can be assumed that all these generations have not the same values, norms or beliefs (Huettinger, 2008). According to G. Hofstede et al. (2010), although the differences between generations (symbols, heroes, rituals and values) are obvious, they are often ocverrated. However, as the authors underline, historical events have a particular impact on some generations. In the period of transformation, as noted by S. Juknevičius (2002), the social tension fields of different socialdemographic groups are characteristic. Lithuania is also attributed to the countries which have undergone various transformations, the transition from the Soviet government to an independent state. G. Jucevičius (2014) also notes the importance of age characteristics in the context of post-Soviet transformation. The author claims that in analysing the distribution of cultural dimensions underlined by G. Hofstede, the research conducted in Lithuania (Lithuanian cultural profile in the aspect of labour values) according to the age groups of respondents, shows a significant tendency - the significance of all cultural dimensions varies considerably with the age of respondents. The older the respondents, the more they are characterized by high power distance (Table 1).

Table 1. Distribution of non-adapted values of cultural dimensions (power distance) by G. Hofstede, according to the respondents' age groups

\begin{tabular}{|l|c|c|c|c|c|}
\hline \multicolumn{1}{|c|}{ Respondents' age } & $\begin{array}{c}\text { Under 24 } \\
\text { years old }\end{array}$ & $\begin{array}{c}25-34 \text { years } \\
\text { old }\end{array}$ & $\begin{array}{c}35-49 \text { years } \\
\text { old }\end{array}$ & $\begin{array}{c}\text { Over 50 years } \\
\text { old }\end{array}$ & Total average \\
\hline $\begin{array}{l}\text { Index of power distance } \\
\text { Average }\end{array}$ & 54.31 & 49.63 & 56.28 & 62.11 & 54.46 \\
\hline $\begin{array}{l}\text { Index of power distance } \\
\text { Average }\end{array}$ & 45.65 & 62.14 & 62.44 & 70 & 62.37 \\
\hline
\end{tabular}

Source: created by the author in accordance with G. Jucevičius (2014).

* In the "I" sample of the organization.

${ }^{* *}$ In the sample of mixed respondents. 
Having assessed the information provided in the official statistics portal of the Lithuanian Department of Statistics (https://osp.stat.gov.lt/infografikas23), it can be seen that teachers' age under 35 in Lithuanian education institutions between 2016 and 2017 made only 8.2 percent, whereas teachers of 35-49 years old made 39.4 percent, and teachers over 50 years old made 52.4 percent. Analysing the statistical information on the heads of Lithuanian education institutions of 2016, provided by the Ministry of Education and Science and Centre of Information Technologies in Education (Lithuanian Education in Numbers, 2016), it can be seen that: the heads under 35 years made 2.93percent, the age group of 35-49 years old - 37percent, and heads over 50 years old they made even 60percent. It is clear that most of teachers and heads are individuals who developed their professional activities not only in the independent Lithuania, but also in the Soviet school. The statistical data shows that the age of heads and teachers in Lithuanian education institutions is quite mature. Therefore, this leads to the question of how exactly this educational community is successful in developing the ideas of distributed leadership in education institutions. There are no comprehensive scientific studies on this issue in Lithuania.

According to the data of the Lithuanian Department of Statistics, at the beginning of 2017, women in Lithuania made 53.9 percent, while men - 46.1 percent of all permanent residents. From the statistical data presented in the publication "Lithuanian Education in Numbers" (Lietuvos Respublikos švietimo ministerija, švietimo techninio aprūpinimo centras, 2016), it is evident that between 2014 and 2015 more than 94percent of teachers working in primary education were women. There is a similar situation in basic and secondary education, where women teachers made more than 82 percent. The situation is slightly different when it comes to the gender of the heads of general education schools: heads (women) of primary education institutions made more than 63 percent, and heads (women) of basic and secondary education institutions made more than 52 percent. Similar data is also available on the Official Statistics Portal of Lithuania - between 2016 and 2017 , even 87.7 percent of women teachers were working in Lithuanian schools.

According to G. Hofstede et al. (2010), social class is associated with educational opportunities and with a person's occupation or profession, social classes carry different class cultures. In Lithuania, there are 31 percent of people with higher education (https://osp.stat.gov.lt/statistiniurodikliu-analize?hash=e93223f1-9a38-4 c54-8a61-ee4d80d24a75\#/). Meanwhile, the data provided on the Official Statistics Portal of Lithuania shows that between 2016 and 2017 even 98percent of teachers in Lithuania had higher education. However, in terms of distributed leadership in Lithuanian education institutions, not only teachers and heads, but also other employees of education institutions are important. There are no studies, statistical data, which would analyse the context of education institutions in the aspect of community's education.

The answers to the main questions describing power distance according to demographic characteristics (gender, 
age and work nature) in the research conducted by G. Jucevičius (2014), in the aspect of work values within Lithuanian cultural profile, prove that the tendency of high power distance is typical for many respondents (except younger with $\mathrm{PhD}$, top level managers and managers in the field of informatics). The author also notes that the answers to the questions of power distance depend on the age factor (younger respondents prefer a democratic governance style, but at the same time do not dare to oppose their leaders). Women, more often than men, notice hierarchical relationships within an organization. The overview of scientific literature, conducted by I. Minelgaitè-Snaebjornsson et al. (2017), also proves that national culture in Lithuania is characterized by high power distance. This was confirmed by the empirical studies conducted by the researchers (the total average of power distance index is 50.39). Respondents indicated that opposing to the head is not a typical practice in the culture. According to I. Minelgaitè-Snaebjornsson et al. (2017), this may be influenced by still felt consequences of the financial crisis of 2008 , i.e., higher unemployment rate, lower salaries, lower bonuses, etc.

In summary, it can be stated that the studies conducted by researchers (Mockaitis, 2002, 2005; Jucevičius, 2014; Minelgaite-Snaebjornsson et al., 2017) on cultural dimensions (including power distance) show that Lithuania is attributed to the countries with high power distance. Since the statistical socio-demographic data (age, gender and education) of Lithuanian education institutions are quite different from the general Lithuanian statistics, it is expedient to conduct separate empirical research evaluating the cultural dimensions of these institutions (and not only the power distance).

\section{Conclusions}

Researchers note that aiming to successfully implement changes within an organization, leadership plays a significant role, and vice versa, staff's resistance to changes, heads' rigidities and the lack of leadership are among the major obstacles for the successful implementation of changes (Gill, 2003; Harris, 2008; Hayes, 2010). Not only leadership in general, but also distributed leadership contribute to people's belief that the structure of rules within an organization is fair, honest, and this facilitates the implementation of other changes in an organization. Distributed leadership in an organization is most often characterized by the following features: the participation of employees in organizational activities, professional sharing of available skills with each other, learning from each other, communication and cooperation to achieve the goals of an organization, high confidence in each other, taking responsibility and accountability for individual activities and collective results, participation in decision making, distribution of power and activity between formal and non-formal leaders, etc. All this can be assessed as a favourable environment for developing knowledge and shaping people's worldview in an organization, for people's belief, that the structure and rules of an organization are fair and honest, and at same time to reduce the cost of management of changes implemented in an organization. According to D. North (2010), 
the decentralization of decision making is essential for the effective performance of an organization. Hence, it is likely that an organization, with the implemented ideas of distributed leadership, will have more streamlined development of new ideas and knowledge, a faster change in people's worldview and the transition from a former situation to the desired cultural and structural changes.

Recently, in Lithuania, the state's aim to spread leadership ideas, to shift leadership as a change or as a basis for successful management of other changes to educational organizations has been noted. The change in the normative documents regulating education activities in Lithuania, the project "Time for Leaders", which has been funded for almost ten years, show that at the state level it is sought to influence the educational communities, to change the existing formal institutes (legal documents, organizational structure) and organizational culture, standards of conduct. Research shows that leadership ideas implemented in education institutions, planned distributed leadership can later become as the basis for the change of organizational culture, and to serve for the successful implementation of other changes in organizations. However, the implementation of leadership ideas (leadership as a change and the basis for implementing other changes) is not regulated in Lithuanian education institutions. It enables each organization to take micro-level strategic actions aiming to optimize their decisions within the organization or take no action, only simulate changes if the organization's obvious cultural and structural changes are not required by institutions controlling the activities of education institutions. It is clear that the heads of education institutions play an important role in developing distributed leadership in the organizations. As the society and normative documents regulating the activities of education organizations make the changes in organizations inevitable, today's formal leaders are forced to change themselves, to change their personality, their attitudes towards organizational changes, to enable other members of the organization to disclose their leadership talent, to change the organization's structure and culture. This often poses difficulties for formal leaders, because their power and authority decrease, difficulties can arise in a transition from management position to leadership and interactions within an organization, and there is the need to trust each other (Harris, 2008, 2012). The situation may fundamentally be changed by the amendments made to the Law on Education of the Republic of Lithuania (1991), which introduced new regulations for the evaluation of the performance of heads, deputyheads for education, heads of departments organizing education, who work in the state (except higher education institutions) and municipal schools, the terms of office for heads were introduced as well. The situation may change since 2018 , after introducing full-time salary for teachers, and this, as it is expected, will attract more of young teachers to education institutions. The age characteristic, as noted by G. Jucevičius (2014), is especially relevant in the context of post-Soviet transformation, since the attitudes and values of different age people have formed in different institutional contexts.

According to G. Jucevičius (2014), G. Hofstede conducted research in 
marketing and product development divisions of IBM corporation in 72 countries of the world. Therefore, some critics of G. Hofstede underline this as one of the main drawbacks of the methodology, because the levels of organizational and national culture, that are not identical, are unduly identified. According to G. Hofstede, et al. (2010), organizational culture is a phenomenon that can differ in many respects from national culture. However, according to the authors, national culture inevitably influences organizational culture and its activities.

Research shows that Lithuania is attributed to the countries with high power distance. In countries with high power distance, the implementation of leadership is more complicated (Mockaitis, Šalčiuviene, 2004). Since the statistical social-demographic data of Lithuanian education institutions are significantly different from the general Lithuanian statistical data, it is expedient to conduct individual studies assessing the cultural dimensions of these institutions (and not only of power distance) for the development of distributed leadership, and only then make reasonable conclusions about the conditions for the development of distributed leadership in Lithuanian education institutions.

According to G. Jucevičius (2014), there is a mutual connection between institutions and organizations as institutions affect organizations and organizations can affect institutional environment. Therefore, it is expedient to conduct empirical studies and evaluate how institutional changes in Lithuania affect education institutions, and what structural and cultural changes have already been implemented in them.

\section{References}

1. Beresnevičiūtè, V., Dagytė, V., Dapkus, G., Katiliūtè, E., Savičiūtè, D. (2011). Longitudinis lyderystès raiškos švietime tyrimas. Internet access: http://www.sac.smm.lt/wp-content/ uploads/2016/01/438_LONGITUDINISLY DERYSTES - RA ISKOS - S VIET IME TYRIMAS.pdf.

2. Brousseau, E., Garrouste, P., Raynaud, E. (2011). Institutional Changes: Alternative Theories and Consequences for Institutional Design // Journal of Economic Behavior and Organization. Vol. 79, No.1-2, pp. 1-53. Internet access: https://pdfs.semanticscholar.org/84ac/ d1373c8d8582d7301b142be09da1e0df38ef.pdf

3. Cibulskas, G., Žydžiūnaitè, V. (2011). Lyderystès vystymosi mokykloje modelis. Vilnius: Mokyklų tobulinimo centras. Internet access: http://www.lyderiulaikas.smm.lt/ Atsisi\%C5\%B3sti\%20failus:/article/809/429_ LYDERYST\%C4\%96S\%20VYSTYMOSI\%20 MOKYKLOJE\%20modelis.pdf.

4. Day, Ch., Sammons, P., Hopkins, D., Harris, A., Leithwood, K., Gu, Q., Brown, E. (2009). Dešimt teiginių apie sèkmingą lyderystę mokyklose. Internet access: http://www.lyderiulaikas.smm.
lt/Atsisi\%C5\%B3sti\%20failus:/article/534/ De\%C5\%A 1 imt\%20teigini\%C5\%B3\%20 apie $\% 20$ s \% C $4 \% 97 \mathrm{~km}$ ing $\%$ C $4 \% 85 \% 20$ lyderyst\%C4\%99\%20mokyklose.pdf.

5. Dambrauskienè, D., Liukinevičienè, L. (2017). Possibilities of Distributed Leadership Development in the Context of Changes: A Case of Pre-School Education Institutions. Management of Organizations: Systematic Research. Vol. 78, pp. 33-47. doi: https://dx.doi.org/10.1515/mosr-2017-0014.

6. Duif, T., Harrison, Ch., van Dartel, N. (2013). Distributed Leadership in Practice. A Descriptive Analysis of Distributed Leadership in European Schools. Internet access: http:// josephkessels.com/sites/default/files/ duijf_e.a._2013_distributed_leadership_in_ practice_esha-etuce_0.pdf.

7. Dukynaitè, R. (2015). Lyderystè: sampratos kvalifikacijos požymiai. - Lietuvos edukologijos universiteto leidykla.

8. Elmore, R. F. (2000). Building a New Structure for School Leadership. The Albert Shanker Institute. Internet access: http://www.shankerinstitute. org/sites/shanker/files/building.pdf. 
9. Fullan, M. (2001). Leading in a culture of change. - San Francisco, CA: Jossey-Bass.

10. Gill, R. (2003). Change Management or Change Leadership? // Journal of Change Management. Vol. 3, No. 4, pp. 307-318. Internet access: http://pateglinton.weebly. com/uploads $/ 2 / 3 / 2 / 5 / 23251384 /$ change management_or_leadership.pdf.

11. Hayes, J. (2010). The Theory and Practice of Change Management. - Palgrave Macmillan.

12. Harris, A. (2008). Distributed Leadership: According to the Evidence // Journal of Educational Administration. Vol. 46, No. 2, pp. 172-188. doi: 10.1108/09578230810863253.

13. Harris, A. (2008). Distributed School Leadership: Developing Tomorrow's Leaders. Paper presented at the 2008 Essex Primary Heads' Association Conference, London. Internet access: http://almaharris.com/ indicative_presentations/distributed_school_ leadership09.pdf.

14. Harris, A. (2010). Pasidalytoji lyderystè mokykloje. Ateities lyderių ugdymas. - Vilnius: Švietimo aprūpinimo centras.

15. Harris, A., Spillane, J. P. (2008). Distributed Leadership Through the Looking Glass // Management in Education. Vol. 22, No. 1, pp. 31-34. doi: 10.1177/0892020607085623.

16. Harris, A. (2012). Distributed Leadership: ImplicationsfortheRoleofthePrincipal//Journal of Management Development. Vol. 31, No. 1, pp. 7-17. doi: 10.1108/02621711211190961.

17. Heikka, J. (2014). Distributed Pedagogical Leadership in Early Childhood Education. Academic Dissertation.

18. Hofstede, G. (1984). Culture's Consequences: International Differences in Work-related Values. - London: Sage. Internet access: https:// books.google.lt/books?hl=lt\&lr=\&id=Cayp Um4O9gC\&oi=fnd\&pg=PA13\&dq=Hofstede ,+G.+(1984).+Culture\%E2\%80\%99s+conseq uences:-International+differences+in+workrelated+values.+London:+Sage\&ots=V4DCGA NNK9\&sig=a7hM929Ks4ooNQWl6IJrw4FYoA $\mathrm{w} \&$ redir_esc $=\mathrm{y} \# \mathrm{v}=$ onepage\&q\&f$=$ false.

19. Hofstede, G. (2007). A European in Asian // Asian Journal of Social Psychology. Vol. 10, pp. 16-21. doi: 10.1111/j.1467-839X.2006.00206.x.

20. Hofstede, G., Hofstede, G. J., Minkov, M. (2010). Cultures and Organizations: Software of the Mind, Third Edition Paperback - May 24.
Internet access: http://testrain.info/download/ Software $\% 20$ of $\% 20$ mind.pdf.

21. Huettinger, M. (2008). Cultural Dimensions in Business Life: Hofstede's Indices for Latvia and Lithuania // Baltic Journal of Management. Vol. 3, No. 3, pp. 359-376. doi: $10.1108 / 17465260810902414$.

22. Jucevičius, G. (2014). Nacionalinès vadybos sistemos: kultūra, institucijos, inovacijos. Mokslo monografija. - KTU leidykla: "Technologija".

23. Juknevičius, S. (2002). Skirtingumo dimensijos. Lietuvos gyventojų vertybès europiniame kontekste. Serija „Lietuvos gyventojų vertybės”. Vilnius: Gervelè.

24. Katiliūtè, D., Malčiauskienè, A., Simonaitienè, B., Stanikūnienè, B., Jezerskyte, E., Cibulskas, G. (2013). Longitudinio lyderystès raiškos švietime tyrimas. Internet access: http://www.svietimas. sakiai.lt/lyderiu_laikas/tyrimas.pdf.

25. Kivunja, Ch. (2015). Leadership in Early Childhood Education Contexts: Looks, Roles, and Functions // Creative Education. No. 6, pp. 1710-1717. doi: http://dx.doi.org/10.4236/ ce.2015.616172.

26. Kroeber., A. L., Klucichohn, C. E. (1952). Culture. A Critical Review of Concepts and Definitions. Papers of the Peabody museum of American Archaeology and Ethnology, Harvard university. Vol. XLVII, No. 1, pp. 3-217. Internet access: http://www.pseudology.org/Psyhology/ CultureCriticalReview1952a.pdf.

27. Koopman, P. L., Den Hartog, D. N., Konrad, E. et al. (1999). National Culture and Leadership Profiles in Europe: Some Results from the GLOBE Study // European Journal of Work and Organizational Psychology. Vol. 8, No. 4, pp. 503-520. Internet access: https://pdfs. semanticscholar.org/1505/279658ccb838e1b77 b406bff51678141c51a.pdf.

28. Leithwood, K., Day, Ch., Sammons, P., Harris, A., Hopkins, D. (2006). Successful School Leadership. What It Is and How It Influences Pupil Learning. Research report. University of Nottingham. Internet access: http://webarchive. nationalarchives.gov.uk/20130401151715/ http://www.education.gov.uk/publications/ eOrderingDownload/RR800.pdf.

29. Lietuvos Respublikos Seimas. Lietuvos pažangos strategija „Lietuva 2030“. (2013).

30. Lietuvos Respublikos švietimo ir mokslo ministerija. (2013). Valstybinè švietimo strategija 2013-2022 m. 
31. Lietuvos Respublikos švietimo ir mokslo ministerija. (2015). Geros mokyklos koncepcija.

32. Lietuvos Respublikos švietimo ir mokslo ministerija. (2015). Valstybinių ir savivaldybių švietimo įstaigų (išskyrus aukštąsias mokyklas) vadovų, jų pavaduotojų ugdymui, ugdymą organizuojančių skyrių vedèjų veiklos vertinimo nuostatai. $2018 \mathrm{~m}$. kovo $27 \mathrm{~d}$. ísakymas Nr. V-279.

33. Lietuvos Respublikos švietimo ministerija, švietimo techninio aprūpinimo centras (2016). Lietuvos švietimas skaičiais. Bendrasis ugdymas. Internet access: https://www.sac.smm.lt/wpcontent/uploads/2016/12/Lietuvos-svietimasskaiciais-2016-Bendrasis-ugdymas-galut..pdf

34. Lietuvos Respublikos Seimas. Lietuvos Respublikos švietimo įstatymas. (1991).

35. Lietuvos Respublikos švietimo ir mokslo ministerija. Lietuvos Respublikos švietimo ir mokslo ministro 2017 m. gegužès 2 d. ịsakymas Nr. V-322.

36. Liu, Y., Bellibas, M., S., Printy, S. (2018). How School Context and Educator Characteristics Predict Distributed Leadership: A hierarchical Structural Equation Model with 2013 TALIS Data // Educational Management Administration \& Leadership. Vol. 46, No. 3, pp. 401-423. doi: $10.1177 / 1741143216665839$.

37. Minelgaitè-Snaebjornsson, I., Runar Edvardsson, I., Littrell, R., F. (2017). Societal Culture in Iceland and Lithuania: Managerial Implications // SAGE Open. doi: 10.1177/2158244017704023.

38. Mockaitis, A. I. (2005). A Cross-Cultural Study of Leadership Attitudes in Three Baltic Sea Region Countries // International Journal of Leadership Studies. Vol. 1, No. 1, pp. 44-63.

39. Mockaitis, A. I. (2002). The National Cultural Dimensions of Lithuania // Ekonomika. No. 59. Internet access: http://etalpykla. lituanistikadb.lt/fedora/get/LT-LDB 0001:J.04 2002 1367180286448/DS.002.1.01. ARTIC.
40. Mockaitis, A. I., Šalčiuvienè, L. (2004). Darbuotojų požiūrių ì vadovavimą Rytų Europos šalyse lyginamoji analizè. Comparative analysis of employees' attitudes towards management in Eastern Europe // Organizacijų vadyba: sisteminiai tyrimai. Vol. 31, pp. 153-166.

41. Murphy, J., Mayrowetz, D., Smylie, M., Seashore, K. L. (2009). The Role of the Principal in Fostering the Development of Distributed Leadership // School Leadership and Management. Vol. 29., No 2., pp. 181-214. doi: $10.1080 / 13632430902775699$.

42. North, D. C. (2003). Institucijos, jų kaita ir ekonomikos veikmè. - Vilnius: Eugrimas.

43. North, D. C. (2010). Understanding the Process of Economic Change. - Princeton, NJ: Princeton University Press.

44. Northouse, P. G. (2009). Lyderystè. Teorija ir praktika. - Kaunas: Poligrafija ir informatika.

45. Obadara, O. E. (2013). Relationship between Distributed Leadership and Sustainable School Improvement // Int J Edu Sci. Vol. 5., No.1, pp. 69-74. Internet access: http://krepublishers. com/02-Journals/IJES/IJES-05-0-000-13-Web/ IJES-05-1-000-13-ABST-PDF/IJES-05-1-06913-166-Obadara-O-E/IJES-05-1-069-13-166Obadara-O-E-Tt.pdf

46. Roland, G. (2004). Understanding Institutional Change: Fast-moving and Slow-moving Institutions // Studies in Comparative International Development. No. 38, pp. 109131. Internet access: https://eml.berkeley. edu/ groland/pubs/gr3.pdf.

47. Valuckienè, J., Balčiūnas, S., Katiliūtė, E., Simonaitienè, B., Stanikūnienè, B. (2015). Lyderyste mokymuisi: teorija ir praktika mokyklos kaitai. - Šiauliai: Titnagas.

The paper submitted: April 27, 2018 Prepared for publication: June 29, 2018 


\section{Dalia DAMBRAUSKIENÉ}

\section{ŠVIETIMO ISTAIGỤ PASIDALYTOSIOS LYDERYSTĖS PRINCIPỤ PLĖTROS IŠŠŪKIAI HIERARCHIŠKOS KULTŪROS KONTEKSTE}

\section{S a n tra u a}

Straipsnyje nagrinèjami Lietuvos švietimo įstaigų pasidalytosios lyderystès principų plètros iššūkiai hierarchiškos kultūros kontekste.

Sprendžiama problema: kokių Lietuvos švietimo įstaigų pasidalytosios lyderystès principų plètros iššūkių kyla hierarchiškos kultūros kontekste.

Tikslas - atskleisti pasidalytosios lyderystès plètros švietimo įstaigose iššūkius hierarchiškos kultūros kontekste.

Straipsnyje apibendrinamas mokslinis požiūris i pasidalytąą lyderystę, atkreipiamas dèmesys ị tai, kad šiuo metu pasidalytoji lyderystè yra dominuojanti vadovavimo ideja, kuri reikšminga siekiant sèkmingai igyvendinti pokyčius organizacijoje. Pasidalytoji lyderystè organizacijoje dažniausiai pasireiškia tokiais požymiais, kuriuos galima įvertinti kaip palankią aplinką organizacijoje žmonių pasauležiūrai formuoti, kaip palankią aplinką žmonių ịsitikinimams, kad organizacijos arba sistemos taisyklių struktūra yra teisinga ir sąžininga. Mokslininkai pastebi, kad sprendimų prièmimo decentralizavimas turi esminès reikšmès efektyviai organizacijos veiklai. Todèl organizacijoje su igyvendintomis pasidalytosios lyderystès idejomis tikètina sklandesnè ir naujų idejų, žinių plètra, spartesnè žmonių pasaulèžiūros kaita ir perèjimas iš buvusios situacijos i norimo igyvendinti pokyčio kultūrinius ir struktūrinius pokyčius.

Pastaruoju metu Lietuvoje stebimas valstybès siekis skleisti lyderystès idejas, perkelti lyderystę kaip pokyti arba kaip pagrindą sèkmingam kitų pokyčių valdymui i švietimo organizacijas. Lietuvoje vykdoma švietimo veiklą reglamentuojančių norminių dokumentą kaita, beveik dešimt metų finansuojamas projektas „Lyderių laikas“ rodo, kad valstybiniu lygmeniu siekiama daryti poveiki švietimo bendruomenems, pakeisti egzistuojančius formalius institutus (teisinius dokumentus, organizacijų struktūrą) ir organizacijų kultūrą, elgesio normas. Moksliniai tyrimai rodo, kad švietimo ịstaigose igyvendintos lyderystès idejos, planuojama ir giluminè pasidalytoji lyderystè vèliau gali tapti organizacijų kultūros kaitos pagrindu, pasitarnauti sėkmingam kitų pokyčių igyvendinimui organizacijose. Tačiau lyderystès idèjų (lyderystė kaip pokytis ir lyderystė kaip pagrindas kitų pokyčių igyvendinimui) igyvendinimas Lietuvos švietimo ịstaigose nèra reglamentuotas. Tai sudaro galimybę kiekvienai organizacijai imtis mikrolygmens strateginių veiksmų siekiant optimaliausių sprendimų būtent toje organizacijoje arba nesiimti jokių veiksmų, pokyčius tik imituoti, jei akivaizdžių organizacijos kultūrinių ir struktūrinių pokyčių nereikalauja švietimo įstaigų veiklą kontroliuojančios institucijos. Akivaizdu, kad didelis vaidmuo, plètojant pasidalytają lyderystę organizacijose, tenka ir švietimo i̦staigų vadovams. Kadangi visuomené, švietimo organizacijų veiklą reglamentuojantys norminiai dokumentai pokyčius organizacijose daro neišvengiamais, formalių lyderių pareigas užimantys asmenys šiandien taip pat priversti keistis patys, keisti požiūrị ị organizacijoje vykstančius pokyčius, sudaryti sąlygas kitiems organizacijoms nariams atskleisti savo lyderystès talentą. Tai neretai kelia sunkumų formaliems lyderiams, nes: sumažèja jų galia ir valdžia, gali kilti sunkumų pereinant iš vadovavimo pozicijos prie lyderystès ir tarpusavio sąveikos organizacijoje, atsiranda poreikis pasitikèti vieni kitais. Situaciją iš esmès gali pakeisti atliktos Lietuvos Respublikos švietimo įstatymo (1991) pataisos, kuriomis ịteisinti nauji valstybinių (išskyrus aukštąsias mokyklas) ir savivaldybių mokyklų vadovų, jų pavaduotojų ugdymui, ugdymą organizuojančių skyrių vedejų veiklos vertinimo nuostatai, įvestos vadovų kadencijos ir kt. Galimai situacija pasikeis ir nuo $2018 \mathrm{~m}$. ịvedus etatini pedagogų darbo apmokejjimą, kas, tikimasi, pritrauks i švietimo įstaigas daugiau jaunų mokytojų.

Moksliniai tyrimai rodo, kad Lietuva priskiriama prie didelès galios distancijos šalių. O galios distancija turi ịtakos lyderystès stiliui organizacijose. Kadangi Lietuvos švietimo isstaigų statistiniai socialiniai ir demografiniai duomenys gerokai skiriasi nuo bendrųjų Lietuvos statistinių duomenų, tikslinga atlikti atskirus empirinius mokslinius tyrimus, kurie įvertintų šių įstaigų kultūrines dimensijas (ir ne tik galios distancijos), organizacijose esančias sąlygas pasidalytosios lyderystès pletrai ir tik tuomet daryti pagrịstas išvadas apie kultūrinès aplinkos sąlygas Lietuvos švietimo įstaigose pasidalytosios lyderystès principų plètrai. Kadangi tarp institucijų ir organizacijų yra abipusis ryšys, todèl tikslinga atlikti empirinius tyrimus bei ịvertinti, kaip konkrečiai Lietuvoje instituciniai pokyčiai veikia švietimo ịstaigas, kokie struktūriniai ir kultūriniai pokyčiai jose jau igyvendinti pastaruoju metu, su kokiais iššūkiais susiduriama. 